\title{
Correction to: DIII-D Research to Prepare for Steady State Advanced Tokamak Power Plants
}

\author{
R. J. Buttery ${ }^{1} \cdot$ B. Covele ${ }^{1} \cdot$ J. Ferron ${ }^{1} \cdot$ A. Garofalo ${ }^{1} \cdot$ C. T. Holcomb ${ }^{2} \cdot$ T. Leonard ${ }^{1} \cdot$ J. M. Park ${ }^{3}$. \\ T. Petrie ${ }^{1} \cdot$ C. Petty ${ }^{1} \cdot$ G. Staebler ${ }^{1} \cdot$ E. J. Strait ${ }^{1} \cdot$ M. Van Zeeland ${ }^{1}$
}

Published online: 19 October 2018

(C) The Author(s) 2018

\section{Correction to: Journal of Fusion Energy https://doi.org/10.1007/s10894-018-0185-y}

The article "DIII-D Research to Prepare for Steady State Advanced Tokamak Power Plants", written by R. J. Buttery, B. Covele, J. Ferron, A. Garofalo, C. T. Holcomb, T. Leonard, J. M. Park, T. Petrie, C. Petty, G. Staebler, E. J. Strait, M. Van Zeeland, was originally published electronically on the publisher's Internet portal (https://doi.org/ 10.1007/s10894-018-0185-y) on 3 September 2018 without open access.

With the author(s)' decision to opt for Open Choice the copyright of the article changed on 4 October 2018 to (C). The Author(s) 2018 and the article are forthwith distributed under the terms of the Creative Commons Attribution 4.0
International License (http://creativecommons.org/licen ses/by/4.0/), which permits use, duplication, adaptation, distribution and reproduction in any medium or format, as long as you give appropriate credit to the original author(s) and the source, provide a link to the Creative Commons License and indicate if changes were made.

The original article has been corrected.

Open Access This article is distributed under the terms of the Creative Commons Attribution 4.0 International License (http://creative commons.org/licenses/by/4.0/), which permits unrestricted use, distribution, and reproduction in any medium, provided you give appropriate credit to the original author(s) and the source, provide a link to the Creative Commons license, and indicate if changes were made.
The original article can be found online at https:// doi.org/10.1007/s10894-018-0185-y.

\footnotetext{
R. J. Buttery

buttery@fusion.gat.com

1 General Atomics, PO Box 85608, San Diego, CA 92186-5608, USA

2 Lawrence Livermore National Laboratory, Livermore, CA, USA

3 Oak Ridge National Laboratory, Oak Ridge, TN, USA
} 